\title{
DON'T SETTLE FOR "THE DEVIL YOU KNOW": THE BENEFITS OF USING COLLABORATIVE LAW RATHER THAN LITIGATION TO RESOLVE EMPLOYMENT DISPUTES
}

\author{
JOHANNAH O'CONNELL*
}

\section{INTRODUCTION}

To check the status of a project, Laura, an employee at a marketing company, made what should have been a routine visit to the company's print shop. ${ }^{1}$ However, during that particular visit, the shop manager approached Laura, directed several lewd comments at her, and attempted to pull her toward him. ${ }^{2}$ Immediately upon leaving the print shop, Laura reported the incident to Matt, her company's legal counsel, who informed her that the shop manager would be reprimanded. ${ }^{3}$ The following week, another female employee told Laura that the shop manager had approached her inappropriately in the parking lot, but she had not reported the incident because the shop manager and the owner of the company were friends; she feared retaliation. ${ }^{4}$ After careful consideration, Laura decided to report the second incident to Matt, without revealing the other female employee's identity. ${ }^{5}$ A week after reporting this second incident, Laura was told that she did not qualify for continued employment under the company's new standards. ${ }^{6}$ This came as a particular shock to Laura, who was under the impression that she was about to be promoted. ${ }^{7}$ Thirty days after reporting the other female employee's experience to Matt, Laura was terminated. ${ }^{8}$ As a result, she decided to pursue legal action against the company for both sexual harassment and retaliation. ${ }^{9}$

Laura consulted with an attorney, who explained the litigation process to her. ${ }^{10}$ This explanation left her with the understanding that if she pursued her claim through litigation, the marketing company's attorney would likely accuse

* J.D. Candidate, 2016, Indiana University Robert H. McKinney School of Law; B.A., 2006, Bridgewater State University, Bridgewater, Massachusetts. I would like to thank my mother for her unfailing support throughout my law school experience. I also would like to thank attorneys Patricia T. McCarter and Caroline G. Beauchamp, of the Nashville, Tennessee law firm McCarter \& Beauchamp, PLLC, for introducing me to collaborative law and Professor Allison Martin for providing her expertise and guidance during the writing process.

1. Sherrie R. Abney, The Evolution of Civil Collaborative Law, 15 TEX. WeSLEyAn L. Rev. 495, 505 (2009).

2. $I d$.

3. $I d$.

4. $I d$.

5. $I d$.

6. $I d$.

7. $I d$.

8. $I d$.

9. $I d$.

10. $I d$. 
her of inviting the shop manager's attention in some way. ${ }^{11}$ Moreover, opposing counsel would likely point to her supposed lack of skills or qualifications as the reason for her termination. ${ }^{12}$ Laura feared that pursuing litigation would force her to relive the incident that had upset her so deeply; therefore, she wanted the dispute to be resolved as quickly as possible. ${ }^{13}$

Fortunately, Laura's attorney also introduced her to collaborative law, ${ }^{14}$ a method of dispute resolution that assists parties in solving their problems through private negotiation without court involvement or intervention. ${ }^{15}$ In a collaborative law case, each party hires a collaboratively-trained attorney and the parties resolve their issues by engaging in a series of four-way settlement conferences designed to maximize efficiency and to anticipate and manage potential conflict. ${ }^{16}$ Employing a "client-centered, interest-based [approach to] problem-solving," 17 collaborative attorneys facilitate communication between the parties instead of controlling discussions or initiating proposals. ${ }^{18}$ Once the parties resolve their issues, the attorneys prepare all of the necessary paperwork and file it with the court. ${ }^{19}$

Although collaborative law has primarily been used in family law disputes, it is "easily adapted to civil and commercial disputes" and has been used to settle employment disputes ${ }^{20}$ involving contract issues, allegations arising from discipline or termination, disputes between co-workers, workplace harassment or bullying, and employee requests for accommodation. ${ }^{21}$ Clients such as Laura have enjoyed the benefits of using collaborative law, rather than litigation, to resolve their disputes. ${ }^{22}$ These benefits include: (1) saving time and money; (2) enjoying greater privacy; (3) having more input in the decision-making process; (4) increasing both parties' compliance with the settlement agreement(s) that they

11. Id.

12. Id.

13. $I d$.

14. Id.

15. Phyllis Rubenstein, Collaborative Law: Effectively Resolving Conflict Without Going to Court, 36 Vt. B.J. (SPeCiAl IsSUE) 40, 40 (2010).

16. $I d$.

17. Id.

18. Id. at 41 .

19. Id. at 40 .

20. Abney, supra note 1, at 498.

21. Civil Collaborative Practice, Int'L ACad. Collaborative Profs., https://www. collaborativepractice.com/professional/resources/civilcommercial-practice-information.aspx [http://perma.cc/ESD2-9KU5] (last visited Oct. 11, 2015).

22. Susan Daicoff, Collaborative Law: A New Tool for the Lawyer's Toolkit, 20 U. FLA. J.L. \& Pub. PoL'y 113, 130-33 (2009); see also Michael A. Zeytoonian, 3 Misconceptions About Using Collaborative Law in Employment Disputes, MEDiATE.COM (Feb. 2014), http://www.mediate. com/articles/ZeytoonianMbl20140228.cfm [http://perma.cc/8NP5-FLYE] (describing litigation as "the devil [you] know" and advocating for the expanded use of collaborative law in resolving employment disputes). 
personally crafted; and (5) effectively mitigating any conflict between the parties. ${ }^{23}$ Likewise, many attorneys who have added collaborative law to their practices assert that collaborative law has positively redefined their relationships with their clients, "making them more satisfying." 24 Some go so far as to describe collaborative law as "a model [of dispute resolution] that [has] influenced their whole approach to the practice of law and even their personal lives." 25

Despite the benefits that both clients and attorneys who utilize collaborative law enjoy, many members of the legal community remain unaware of its existence. ${ }^{26}$ This is partially attributable to the fact that law schools primarily prepare students to participate in the adversarial dispute resolution process and offer few, if any, courses that discuss collaborative law. ${ }^{27}$ Additionally, some within the legal and business communities who are aware of its existence express reluctance to use collaborative law as a means of resolving employment disputes. ${ }^{28}$ Such reluctance is due, in part, to misconceptions held by employers regarding the implementation of collaborative $\operatorname{law}^{29}$ and, in part, to objections raised by corporate and business attorneys to the disqualification requirement contained in collaborative law participation agreements. ${ }^{30}$

The purpose of this Note is to introduce law students and attorneys to collaborative law and its benefits and to advocate for its expanded use in resolving employment disputes. Part I of this Note provides an introduction to collaborative law and Part II discusses the unique characteristics that distinguish this method of dispute resolution from arbitration and mediation. Part III explores the ways in which collaborative law has been applied effectively to resolve family law disputes and how ethical concerns regarding its application have been addressed. Finally, Part IV discusses how collaborative law may successfully address several types of employment law disputes and addresses objections to using collaborative law that have been raised by employers and business and employment attorneys, respectively.

\section{Id.}

24. Dafna Lavi, Can the Leopard Change His Spots?! Reflections on the "Collaborative Law” Revolution and Collaborative Advocacy, 13 CARdozo J. Conflict Resol. 61, 92 (2011).

25. Id.

26. Abney, supra note 1, at 513.

27. $I d$.

28. See Diana Fitzpatrick, Using Collaborative Law to Resolve Business/Commercial Disputes, NoLO, http:/www.nolo.com/legal-encyclopedia/collaborative-law-business-commercialdisputes-30152.html [http://perma.cc/JJG8-Z7CU] (last visited Oct. 11, 2015) (discussing objections raised by attorneys to collaborative law's disqualification requirement); Zeytoonian, supra note 22 (outlining three major objections raised by employers to the use of collaborative law).

29. Zeytoonian, supra note 22.

30. Fitzpatrick, supra note 28. 


\section{INTRODUCTION TO COLLABORATIVE LAW}

\section{A. Creation by Stuart Webb}

Stuart Webb, a Minneapolis family lawyer, created the concept of collaborative law in 1990 in response to his growing frustration with the impact that the adversarial system had on his clients and on his own well-being. ${ }^{31}$ This frustration, Webb explained, stemmed from the overwhelming feeling that, as a divorce litigator, he was "living in a siege mentality[,] merely waiting for the next battle to start." ${ }^{\prime 32}$ Consequently, he developed a dispute resolution model in which attorneys operated as "settlement-only specialists ... who [only would] work with the [divorcing] couple outside [of] the court system.", ${ }^{33} \mathrm{He}$ founded this model on the idea that removing the threat of one party's taking the other to court was "the only way for lawyers to engage wholeheartedly in interest-based bargaining and dispute resolution processes." ${ }^{34}$

In 1992, Dr. Peggy Thompson and Dr. Rodney Nurse, two family psychologists in the San Francisco area, began working with a group of attorneys and financial professionals to develop a method of assisting divorcing couples in a supportive way. ${ }^{35}$ Along with Pauline Tesler, a San Francisco attorney and a pioneer of the collaborative law movement, they developed an interdisciplinary collaborative model. ${ }^{36}$ In this model, the divorcing couple retains a "team" of professionals, including collaborative attorneys, a divorce coach for each party, a financial neutral, and, if applicable, a child specialist. ${ }^{37}$

Initially, Webb's model, which employed only attorneys, was referred to as "Collaborative Law," and Dr. Thompson's interdisciplinary model was referred to as "Collaborative Divorce." ${ }^{38}$ Today, however, because so many variations of these two models have emerged, the term "Collaborative Practice" is typically used to describe all collaborative cases. ${ }^{39}$

In 1997, a group led by Tesler and Dr. Thompson established an organization that is known today as the International Academy of Collaborative Professionals ("IACP"). ${ }^{40}$ The IACP strives to "support excellence in Collaborative Practice through [providing] resources, training curricul[a], practice tools, [and] mentoring

31. Gary L. Voegele et al., Collaborative Law: A Useful Tool for the Family Law Practitioner to Promote Better Outcomes, 33 WM. Mitchell L. Rev. 971, 974 (2007).

32. Daicoff, supra note 22, at 117 (quoting Stuart Webb).

33. Voegele et al., supra note 31 (quoting Stuart G. Webb \& Ronald D. Ousky, The Collaborative Way to Divorce xv (2006)).

34. Jennifer W. Reynolds, Luck v. Justice: Consent Intervenes, But for Whom?, 14 PEPP. DisP. RESOL. L.J. 245, 271 (2014).

35. Voegele et al., supra note 31, at 976.

36. Id.

37. Id.

38. Id. at 977.

39. Id.

40. Id. 
[programs] and [by maintaining] a comprehensive website." ${ }^{41}$ In furtherance of its objectives, the IACP also promulgates professional standards and ethical guidelines for collaborative trainers and practitioners. ${ }^{42}$

\section{B. Collaborative Attorneys' Rates and Training}

In a collaborative law case, each party retains a specially trained collaborative attorney for the purpose of resolving the dispute through negotiation without the need for court intervention. ${ }^{43}$ Like litigation attorneys, collaborative lawyers typically charge by the hour and, as with their litigator counterparts, their rates vary $^{44}$ based on their respective levels of experience, operating expenses, and practice locations. ${ }^{45}$ At least one prominent collaborative law firm, the Boston Law Collaborative, LLC, publishes its attorneys' rates as ranging between $\$ 350$ and $\$ 550$ per hour and specifies that these rates "apply to both legal services and dispute resolution services." ${ }^{.46}$ To provide some perspective, the average hourly rate for a partner at a Boston firm in 2012 was $\$ 598.69 .^{47}$ Regardless of the rate that he or she charges, a collaborative attorney should provide his or her client with a retainer agreement that clearly outlines the attorney's hourly rate and the amount of any retainer that is required. ${ }^{48}$

On October 22, 2014, the IACP revised its Minimum Standards for Collaborative Practitioners. ${ }^{49}$ The Minimum Standards for Collaborative Lawyer Practitioners require that a collaborative attorney: (1) maintain membership, in good standing, in the administrative body that regulates and governs attorneys in his or her jurisdiction; (2) complete an Introductory Collaborative Practice Training or an Introductory Interdisciplinary Collaborative Practice Training that conforms to the IACP's minimum standards; (3) participate in at least one thirty-

41. IACP-Connecting the Global Collaborative Community, InT'L ACAD. COLLABORATIVE PROFS., https://www.collaborativepractice.com/public/about/about-iacp/history.aspx [https://perma. cc/L2QP-FD9J] (last visited Sept. 13, 2015).

42. $I d$.

43. Rubenstein, supra note 15.

44. Collaborative Practice FAQs, Ithaca Area Collaborative L. Profs., http://collablaw.com/faq/\#12 [http://perma.cc/K5FX-EB88] (last visited Sept. 13, 2015).

45. How, and How Much, Do Lawyers Charge?, LAWYERS.COM, http://research.lawyers.com/ how-and-how-much-do-lawyers-charge.html [http://perma.cc/7LPF-Q2D7] (last visited Oct. 11, 2015).

46. About Us, Bos. L. Collaborative, LLC, http://www.bostonlawcollaborative.com/ blc//faqs/about-blc-boston-law-collaborative.html [http://perma.cc/TZ5H-5Q5Y] (last visited Oct. 11, 2015).

47. Brandon Gee, The Going Rate(s), Mass. LAw. WKLY. (Oct. 11, 2013), http:// masslawyersweekly.com/2013/10/11/the-going-rates/ [http://perma.cc/UF8B-QZAK].

48. Collaborative Practice FAQs, supra note 44.

49. IACP Minimum Standards for Collaborative Professionals (Adopted July 13, 2004: Revised October 22, 2014), INT'L ACAD. COLlaborative ProfS., https://www.collaborative practice.com/media/98357/Collaborative_Practitioner_Standards_Oct._2014.pdf [http://perma.cc/7RJC-M97Y] (last visited Sept. 13, 2015). 
hour training in client-centered, facilitative conflict resolution of the type typically taught in mediation training; and (4) accumulate fifteen hours of training in a wide array of skills, including negotiation and communication techniques. ${ }^{50}$ Although these standards "are intended to serve as a guidebook rather than a rulebook," the IACP "urges practice groups to adopt and use IACP Standards to enhance the quality of local practice ... [and] to foster a consistent and shared understanding of what it means to strive for excellence as a Collaborative practitioner. ${ }^{51}$ Moreover, the IACP believes that these standards will promote a common understanding of collaborative practice among collaborative professionals, clients, the judiciary, and the public. ${ }^{52}$

\section{Overview of a Collaborative Law Case}

To progress toward resolution, the parties and their respective attorneys engage in a series of four-way settlement conferences. ${ }^{53}$ Prior to each conference, the collaborative attorneys communicate to develop an agenda for the meeting and to discuss methods for managing any potential conflict that may arise between the parties. ${ }^{54}$

At the first four-way meeting, the parties and their attorneys review, as a group, a collaborative law participation agreement, which must be signed by both parties and their attorneys before the collaborative process may begin. ${ }^{55}$ The collaborative attorneys explain the parties' duties to negotiate in good faith, to exchange all information freely without resorting to formal discovery, and to retain any necessary neutral experts jointly. ${ }^{56}$ Most importantly, the attorneys ensure that the parties understand two fundamental provisions of the participation agreement. ${ }^{57}$ The first provision, although not strictly binding, requires that the parties acknowledge their intent to resolve the dispute without resorting to judicial intervention. ${ }^{58}$ The binding second provision, known as the disqualification requirement, stipulates that if the parties fail in their efforts to resolve the dispute through settlement conferences and wish to take their case to court, their collaborative attorneys will be disqualified from participating in the litigation. ${ }^{59}$

Once the parties and their attorneys sign the participation agreement, the remainder of the first four-way conference gives the parties an opportunity to

50. Id.

51. IACP Standards and Ethics, Int'L ACAD. Collaborative Profs., https://www. collaborativepractice.com/professional/resources/iacp-standards-and-ethics.aspx [http://perma.cc/MQ7A-ZTUH] (last visited Oct. 11, 2015).

52. $I d$.

53. Rubenstein, supra note 15.

54. Id.

55. Id. at 41 .

56. $I d$.

57. Id.

58. Id.

59. Id. 
articulate their goals and interests and to discuss a roadmap for the collaborative process. ${ }^{60}$ "It is essential for the parties to identify broad goals so that, if they become mired in unproductive discussions in future four-way meetings, they can be reminded of their loftier intentions." ${ }^{, 61}$ Notably, there are no proposals exchanged at the first meeting because that would be considered premature and could potentially hinder the collaborative process. ${ }^{62}$

Once the parties exchange and review one another's information, they may begin developing options for addressing their problems and concerns in subsequent meetings. ${ }^{63}$ During these meetings, the collaborative attorneys neither speak for their clients nor initiate proposals. ${ }^{64}$ Instead, they facilitate communication and ensure that the parties have a safe environment in which to express themselves fully and understand one another. ${ }^{65}$ The attorneys typically alternate preparing minutes from each meeting, which they then circulate among the parties. ${ }^{66}$ Additionally, after each conference, the attorneys meet individually with their clients and communicate with one another. ${ }^{67}$ The four-way meetings continue until the parties reach a settlement on all of the issues, at which point the attorneys draft all necessary documents for the parties to sign. ${ }^{68}$

\section{Legal Contexts in Which Collaborative Law Has Been Used}

Given collaborative law's invention by a family law attorney and its early development in divorce cases, it is not surprising that collaborative law has most frequently been applied in family law cases. ${ }^{69}$ Yet, the principles that apply to the use of collaborative law in the family law context apply equally to its use in civil and commercial matters, such as: (1) employment disputes; (2) disputes and restructurings within family-owned businesses or partnerships; (3) probate and trust and estates contests; (4) healthcare conflicts; and (5) construction claims. ${ }^{70}$

\section{Comparison of Collaborative Law, Arbitration, and Mediation}

Currently, the two most common forms of alternative dispute resolution are

60. Id.

61. Id.

62. Id.

63. Id.

64. Id.

65. Id.

66. Id.

67. Id.

68. Id.

69. Id. at 40 .

70. Civil \& Commercial Application of Collaborative Practice, INT'L ACAD. COLLABORATIVE Profs., https://www.collaborativepractice.com/public/about/about-collaborativepractice/civil-commercial-application-of-collaborative-practice.aspx [http://perma.ce/7V9U-462C] (last visited Oct. 11, 2015,). 
arbitration and mediation. ${ }^{71}$ Although collaborative law does share some characteristics with arbitration and mediation, it is a unique form of dispute resolution that offers particular benefits to clients.

\section{A. Comparing Collaborative Law and Arbitration}

Arbitration is perhaps the form of alternative dispute resolution that is most easily distinguishable from collaborative law. Unlike collaborative law, arbitration leaves the ultimate decision-making authority in the hands of the arbitrator, rather than in the hands of the parties. ${ }^{72}$ For all intents and purposes, arbitration is a "simplified version of a trial involving limited discovery and simplified rules of evidence." 73 Therefore, even if arbitration does take place outside of the traditional courtroom setting, it forces parties to engage in hearings before the arbitrator or arbitral panel. ${ }^{74}$ Additionally, arbitration establishes the arbitrator's or panel's written decision as the ultimate authority on the outcome of the matter, ${ }^{75}$ much as a judge's final order determines the outcome of a case that proceeds to trial.

Some parties to collaborative cases choose to employ a mental health professional known as a "coach." ${ }^{, 6}$ The IACP clearly maintains that coaches serve a neutral role. ${ }^{77} \mathrm{~A}$ coach's role, unlike the role of an arbitrator, is not to determine the outcome of the case or even to give legal advice; rather, it is to facilitate communication between the parties and to help them navigate the emotions that arise as a result of their dispute. ${ }^{78}$ Specifically, coaches are trained to identify interpersonal dynamics of which other professionals may be unaware and to use their understanding of such dynamics to assist parties in finding creative solutions that meet their actual emotional needs. ${ }^{79}$ In this way, coaches help to ensure that parties' final agreements are not the product of "mutual misunderstandings and power struggles." $" 80$

Additionally, collaborative law is, first and foremost, a "voluntary dispute

71. Alternative Dispute Resolution, CORNELL U.L. SCH., http://www.law.cornell.edu/ wex/alternative_dispute_resolution [http://perma.cc/KWW9-MGBM] (last visited Oct. 11, 2015).

72. Fitzpatrick, supra note 28.

73. Alternative Dispute Resolution, supra note 71.

74. Id.

75. Id.

76. What Is Collaborative Practice?, InT'L ACAD. Collaborative Profs., https://www. collaborativepractice.com/public/about/about-collaborative-practice/what-is-collaborativepractice.aspx [http://perma.cc/2U86-VU95] (last visited Oct. 11, 2015).

77. Glossary of Terms, InT'L ACAD. Collaborative Profs., https://www.collaborative practice.com/public/about/about-collaborative-practice/glossary-of-terms.aspx [http://perma.cc/NXQ2-F5AE] (last visited Oct. 11, 2015).

78. Id.

79. Kate van Dyke \& Gary Walls, Divorce Coaches in the Collaborative Divorce Process, COLlaborative L. INST. ILlinOIS (2009), http://collablawil.org/wp-content/uploads/2012/03/ Collab_Divorce_Coach_Article.pdf[http://perma.cc/8TVM-PCHH].

80. Id. 
resolution process, ${ }^{, 81}$ whereas arbitration may be either voluntary or mandatory. ${ }^{82}$ In fact, most arbitrations arise from the presence of an arbitration clause in a contract, even if one party to the contract signed the arbitration agreement unknowingly. ${ }^{83}$ If the arbitration clause at issue subjects the parties' dispute to mandatory arbitration, the parties forfeit their rights to sue in court, to participate in a class action lawsuit, and to appeal the arbitrator's decision. ${ }^{84}$ In contrast, although the parties in a collaborative case do subject themselves to the attorney disqualification requirement of the collaborative law participation agreement, they do not give up their right to bring their case before a judge. ${ }^{85}$

Collaborative attorneys are dedicated not only to their respective clients, but also to the overall "client-centered, interest-based [approach to] problemsolving. ${ }^{, 86}$ In contrast, one of the parties often chooses the arbitrator, typically the party that possesses more money and influence.$^{87}$ As a result, arbitrators are more likely to be biased in favor of the appointing party. ${ }^{88} \quad$ The only significant area of overlap between arbitration and collaborative law is the privacy element. Both arbitration proceedings and collaborative law settlement conferences are held in private. ${ }^{89}$ Additionally, in cases settled using these two forms of dispute resolution, the terms of the parties' final agreement may be kept confidential. ${ }^{90}$ Yet, some critics fear that the private nature of arbitration increases the likelihood that the process will be tainted or biased, particularly due to the fact that courts rarely review arbitration decisions. ${ }^{91}$

\section{B. Comparing Collaborative Law and Mediation}

Although mediation, like collaborative law, does give the parties ultimate control over the outcome of their dispute, it differs from collaborative law in several significant ways. ${ }^{92}$ For instance, although mediation allows the parties to resolve their dispute outside of the courtroom, parties often do not utilize mediation until litigation has been initiated.$^{93}$ By that time, one or both of the parties may be "entrenched in positions that are generally based on emotions

81. What Is Collaborative Practice?, supra note 76.

82. Arbitration Basics, NoLO, http://www.nolo.com/legal-encyclopedia/arbitration-basics29947.html [http://perma.cc/X57H-SBEM] (last visited Oct. 11, 2015).

83. Id.

84. Id.

85. See generally Rubenstein, supra note 15.

86. Id. at 40 .

87. Arbitration Pros and Cons, Nolo, http://www.nolo.com/legal-encyclopedia/arbitrationpros-cons-29807.html [http://perma.cc/KT7B-52GX] (last visited Oct. 11, 2015); UNIF. Collaborative Law ACT prefatory note (Unif. LAW COMM'N 2009).

88. Id.

89. Id.

90. Id.

91. Id.

92. Rubenstein, supra note 15 , at 41.

93. Abney, supra note 1, at 496. 
more than [on] the facts of the case." ${ }^{94}$ In fact, most parties do not employ mediation as a method of dispute resolution "until litigation is well under way and discovery has been completed. ${ }^{95}$ This is due, in part, to the fact that mediation does not have an effective information exchange process built into its structure. ${ }^{96}$

In contrast, a collaborative law case is ideally commenced before a lawsuit is filed,${ }^{97}$ when the parties have a far greater chance of "preserving relationships, saving money, achieving a quick resolution and avoiding the draining of resources and emotions. ${ }^{.98}$ However, parties to a lawsuit that has already been filed may decide to abandon litigation and pursue a resolution to their dispute through collaborative law. ${ }^{99}$ In such a case, the collaborative attorney will likely request that the suit be dismissed or obtain a stay from the court to ensure that the collaborative process may proceed without the coercion and pressures imposed by the parties' involvement in an active court case. ${ }^{100}$ For instance, obtaining a dismissal or a stay ensures that the parties cannot be ordered by the court to participate in a variety of forms of dispute resolution, including mediation, even over the objection of one or both of the parties. ${ }^{101}$

Unlike collaborative law, mediation still allows a neutral middleperson to guide and control the parties' negotiations. ${ }^{102}$ For instance, a mediator may formulate settlement proposals and options for consideration. ${ }^{103}$ In the collaborative process, the parties are the only participants allowed to make settlement proposals; the collaborative attorneys serve primarily as active listeners and ask questions that are designed simply to facilitate communication between the parties. ${ }^{104}$ This distinction is significant because mediators often emphasize the statutory, common law, and local origins of the suggestions that they make to parties. ${ }^{105}$ Such emphasis may pressure parties into accepting

94. Id.

95. Michael A. Zeytoonian, One Key Difference Between Mediation and Collaborative Law is Often Overlooked, MEDiATE.COM (Feb. 2012), http://www.mediate.com/articles/Zeytoonian Mbl20120228.cfm [http://perma.cc/YT3R-LMV7].

96. Id.

97. Collaborative Law FAQs, Collaborative Prac. Inst. Michigan, http://www. collaborativepracticemi.org/faq.php\#q5 [http://perma.cc/MJD2-M8PG] (last visited Oct. 11, 2015).

98. Zeytoonian, supra note 95.

99. Collaborative Law FAQs, supra note 97.

100. Id.

101. Richard Barron, Which Cases Are Most Suitable For Court Ordered Mediation, MEDiATE.COM (Oct. 2004), http://www.mediate.com/articles/barronmr1.cfm [http://perma.cc/ 4TML-JMRR].

102. Fitzpatrick, supra note 28.

103. Jim Melamed, Frequently Asked Questions About Mediation and Negotiation, MEDIATE.COM, http://www.mediate.com/articles/Mediationfaq.cfm\#roles [http://perma.cc/SRU5W8EW] (last visited Oct. 11, 2015).

104. Rubenstein, supra note 15 , at 41 .

105. Abney, supra note 1, at 496. 
settlements because they feel threatened or overwhelmed rather than because they feel that their concerns have been addressed. ${ }^{106}$ Further, if the parties settle through mediation for the wrong reasons, their dissatisfaction may lead them to pursue additional legal action in the future. ${ }^{107}$

Another disadvantage of the mediation model is that it focuses the dispute resolution process on the efforts of one person - the mediator-thereby making him or her the key to the process's success. ${ }^{108}$ Because the mediator functions as the "go-between," neither the parties nor their lawyers collaborate with one another; rather, they rely on the mediator's communication skills. ${ }^{109}$ Conversely, in a collaborative law case, "the focal point is not any one person; it is the collaboration itself." 110 Consequently, collaborative law channels the collective ability of the parties and the collaborative attorneys into an integrated effort in which all participants in the process build on one another's ideas and suggestions, regardless of who proposes them. ${ }^{111}$

Additionally, "a mediator does not have the authority to address one party's lack of commitment" to the mediation process, as demonstrated by his or her refusal to produce information or choice to engage in delay tactics. ${ }^{112}$ Similarly, a mediator may be unable to address a situation in which there is an imbalance of knowledge or power between the parties. ${ }^{113}$ In contrast, a collaborative attorney is armed with both the collaborative law participation agreement and the list of goals articulated by the parties during the first four-way meeting. ${ }^{114}$ These tools may be used to remind a recalcitrant party of the reasons why he or she wished to participate in the collaborative process in the first place. ${ }^{115}$

\section{How Collaborative Law Has Been Used EfFectively in THE FAMILY LAW CONTEXT}

\section{A. Benefits of Using Collaborative Law in Family Law Cases}

Collaborative family law attorneys assert that litigation is more expensive, time-consuming, draining, and damaging to relationships than collaborative law. ${ }^{116}$ For example, litigated cases may take two years or more to conclude, even with mandatory pre-suit mediation, whereas the average number of collaborative meetings required for the parties to reach a settlement agreement is eight, for a

106. Id.

107. Id.

108. Zeytoonian, supra note 95.

109. Id.

110. Id.

111. Id.

112. Rubenstein, supra note 15 , at 41 .

113. Id.

114. $I d$.

115. Id.

116. Zeytoonian, supra note 22. 
total of 15.2 hours. ${ }^{117}$ A study featured in Money magazine reported that the average cost of a collaborative divorce was $\$ 16,000 .{ }^{118}$ In contrast, a divorce case resolved through the traditional attorney-to-attorney negotiation method cost $\$ 35,000 .{ }^{119}$ Divorce trials cost a minimum of $\$ 20,000-\$ 50,000 .{ }^{120}$

Although it is always in a party's best interests to spend less time, money, and energy on a legal dispute, this is particularly true when the parties to a family law dispute have children who require their attention and support. ${ }^{121}$ Empirical research shows that even the temporary absence of effective parenting during the parties' divorce may lead to poor family functioning once the divorce is completed. ${ }^{122}$ Therefore, in providing divorcing parents with more time to spend with their children during a critical time in their lives, the collaborative process may have a directly positive effect on the post-divorce condition of the entire family. ${ }^{123}$

Since most, if not all, of a collaborative case may take place outside of the courtroom, the parties enjoy greater privacy than they would have in the traditional litigation process. ${ }^{124}$ In fact, if the parties are able to reach a full agreement, then the only time at which a formal court proceeding takes place is at the very end of the process; therefore, personal information is much less likely to be disclosed. ${ }^{125}$

Additionally, the parties in a collaborative law case are likely to experience greater "satisfaction with the process and outcome and[,] consequently, better compliance with the settlement agreement." ${ }^{, 26}$ This is because collaborative law allows parties to have more input in the ultimate outcome of their case and because clients are likely to feel that they are treated with dignity and respect. ${ }^{127}$ Likewise, by avoiding the animosity and hostility often associated with litigation, collaborative law may reduce conflict between the parties and allow them to maintain a workable, cooperative relationship once they settle the case. ${ }^{128}$

Collaborative law also provides the parties with greater access to neutral, non-lawyer experts, who may provide a "more balanced and useful view of their concerns" than experts participating in the litigation process. ${ }^{129}$ This allows the

117. Daicoff, supra note 22, at 130 (citing the results of an IACP study covering the period from October 15, 2006 through December 31, 2007).

118. The Cost of Divorce: Three Processes, Mediation Matters, http://www.mediation matters.com/the_cost_of_divorce.php [http://perma.cc/9A88-S5KU] (last visited Oct. 11, 2015).

119. Id.

120. Id.

121. Daicoff, supra note 22, at 130.

122. Id. at 130-31.

123. Id. at 131 .

124. Id.

125. Id.

126. Id.

127. Id. at 131-32.

128. Id. at 133.

129. Id. at 134. 
parties to make decisions that produce the best "financial and psychological outcome." $" 130$

\section{B. How Critics' Ethical Concerns Have Been Addressed in the Family Law Context}

Critics of the use of collaborative law in family law cases have voiced concerns about the possible ethical issues that it poses, particularly with regard to the attorney disqualification provision. ${ }^{131}$ Nevertheless, a growing number of states have enacted statutes and created court rules that recognize collaborative law as a legitimate form of dispute resolution in family law matters. ${ }^{132}$ Additionally, the American Bar Association ("ABA") has addressed several of the most common ethical concerns in its opinions. ${ }^{133}$

The disqualification requirement contained in collaborative law participation agreements is a defining characteristic of collaborative law in that it is not found in any other dispute resolution model. ${ }^{134}$ Moreover, there is a clear consensus among collaborative practitioners that a case may not be considered collaborative unless there exists between the parties and their attorneys an agreement regarding the disqualification requirement. ${ }^{135}$ Critics of collaborative law argue that the disqualification requirement is unethical and a violation of ABA Model Rule of Professional Conduct 1.16 because it allows attorneys to withdraw from representation precisely at the time when their clients may need their assistance the most-when litigation becomes necessary. ${ }^{136}$ However, the ABA Standing Committee on Ethics and Professional Responsibility issued an ethics opinion in November 2007 explicitly finding that this feature of collaborative law is ethical, as long as clients provide their informed consent. ${ }^{137}$

Additionally, collaborative practitioners argue that the disqualification requirement removes the "tendency for attorneys and clients to 'drift to court' without fully exploring settlement options," thereby creating a higher level of commitment among all those involved in a collaborative case. ${ }^{138}$ This higher level of commitment, in turn, "leads to outcomes of a much higher quality." 139 Most cases settle before trial, but when one or both clients run out of money or emotional energy in the midst of the adversarial process, they may be prompted to settle out of necessity or due to external pressure rather than because of their satisfaction with the actual proposal. ${ }^{140}$ However, the level of commitment in

130. $I d$.

131. Voegele et al., supra note 31, at 1010-11.

132. Id. at 1011.

133. Daicoff, supra note 22, at 125.

134. Voegele et al., supra note 31 , at 978.

135. Id.

136. Susan B. Apel, Collaborative Law: A Skeptic's View, 30 VT. B.J. 41, 42 (2004).

137. Daicoff, supra note 22, at 125.

138. Voegele et al., supra note 31 , at 979.

139. Id.

140. Id. 
collaborative cases produces different results by " "reduc[ing] the posturing and gamesmanship" of traditional negotiation. ${ }^{141}$ Collaborative practitioners also argue that the disqualification requirement creates a safe environment in which the parties may identify the best outcomes for their specific situation. ${ }^{142}$ This, in turn, solves the "prisoner's dilemma," in which a party, uncertain of the opposing party's next move, feels compelled to compete rather than to cooperate. ${ }^{143}$

Critics also argue that, if the collaborative process breaks down, clients will end up spending more money than they would have if they engaged in another form of dispute resolution. ${ }^{144}$ However, proponents of collaborative law note that cases where the process breaks down are relatively rare and assert that "the value of [the disqualification requirement] is worth the risk of failure and the expense of [obtaining] new counsel."145

\section{How Collaborative Law Can Be Used EfFectively in the EMPLOYMENT LAW CONTEXT}

Just like any development in the legal field, collaborative law has been met with some criticism. ${ }^{146}$ Specifically, employers, who are potential parties to employment disputes, and business and employment attorneys, who potentially may be called upon to participate in collaborative practice, have raised objections to its use in employment disputes. ${ }^{147}$ Yet, in addressing these objections, the benefits of resolving employment disputes through the collaborative process become clear. ${ }^{148}$

\section{A. Addressing Objections Raised by Employers}

1. Unfounded Reluctance to Use a New Form of Dispute Resolution.Employers have offered several explanations for why they would rather use litigation than collaborative law to resolve employment disputes. ${ }^{149}$ For example, employers suggest that it is unwise to use a form of dispute resolution that is relatively new and does not have a track record like litigation. ${ }^{150}$ Consequently,

141. Id. at 979-80 (quoting Julie MacFarlane, Dep't of Justice Can., The Emerging Phenomenon of Collaborative Family Law (CFL): A Qualitative Study of CFL Cases ix (2005)).

142. Id. at 980 .

143. Id. at 981 .

144. Daicoff, supra note 22, at 124-25.

145. Id. at 125 .

146. Zeytoonian, supra note 22.

147. See id. (identifying three primary objections raised by employers to using collaborative law to settle employment disputes); Fitzpatrick, supra note 28 (discussing employment and business attorneys' hesitation regarding the disqualification provision contained in collaborative law participation agreements).

148. Zeytoonian, supra note 22.

149. Id.

150. $I d$. 
employers resign themselves to the idea that the costs of litigation, while expensive, are part of the cost of doing business. ${ }^{151}$

With regard to the argument that collaborative law is an untried dispute resolution technique, critics of mediation used a similar argument in the early 1980 s; today, mediation is the "process of choice" for many parties. ${ }^{152}$ Although collaborative law is a relatively new form of dispute resolution, its use has grown exponentially since its creation in $1990 .{ }^{153}$ In fact, collaborative law has been dubbed the "'hottest area in dispute resolution" "154 and may be found in the major cities of virtually every state in the United States. ${ }^{155}$

Moreover, collaborative law has gained popularity internationally, as evidenced by the fact that the IACP now has over 5000 members practicing in twenty-four countries. ${ }^{156}$ In Canada, the traditional litigation method formerly employed in family law cases "has practically been abandoned in favor of collaborative law." "157 Similarly, Great Britain has adopted collaborative law "in an attempt to find 'broad' solutions for various kinds of disputes, including criminal cases," 158 and Australia has embraced collaborative law "in a broad and advanced fashion, even in comparison to the United States." 159

Additionally, although employers may be willing to accept litigation expenses, these costs may carry severe consequences both for companies and for society as a whole. ${ }^{160}$ Specifically, "[1]itigation can bankrupt small businesses[,] while large corporations pass their litigation costs onto their consumers in the form of higher prices for their products and services." 161 Wanting to reduce litigation costs, a number of large corporations have opted to use collaborative law to settle their disputes outside of the courtroom. ${ }^{162}$ In the process, these corporations "have saved millions of dollars in litigation fees and managed to retain positive relationships with the other parties to disputes."163

Furthermore, the fair treatment of employees, as exhibited by employers using the collaborative process, is an excellent way to improve employee morale and increase productivity. ${ }^{164}$ Allowing employees to discuss their grievances in a private, collaborative setting may assist employers in retaining valuable

151. Id.

152. $I d$.

153. Voegele et al., supra note 31, at 975-76.

154. Id. (quoting Jill Schachner Chanen, Collaborative Counselors: Newest ADR Option Wins Converts, While Suffering Some Growing Pains, Am. B. Ass'N J. 52, 54 (2006)).

155. Daicoff, supra note 22, at 118.

156. IACP-Connecting the Global Collaborative Community, supra note 41.

157. Lavi, supra note 24 , at 77.

158. Id.

159. Id. at 78 .

160. Abney, supra note 1 , at 500 .

161. Id.

162. Id.

163. Id.

164. Id. at 499 . 
employees and, consequently, in reducing the costs of training replacements. ${ }^{165}$

Similarly, the control and flexibility that collaborative law affords with regard to scheduling the time and location of meetings may ensure that neither an employer's nor an employee's time is wasted. ${ }^{166}$ The parties may meet in any mutually-agreeable location; they do not need to worry about jurisdiction or choice of law issues, which are not considerations in the collaborative law process. ${ }^{167}$ The parties are not at the mercy of court schedules and overcrowded dockets, which may significantly slow the dispute resolution process in litigated cases. ${ }^{168}$ Employment disputes may be resolved through collaborative law "within days or weeks, [thereby] relaxing tensions and allowing employees to concentrate on their work instead of wondering what is going to happen next."169

Collaborative law also provides employers with greater privacy than they would enjoy by participating in litigation, ${ }^{170}$ thereby assisting them in preserving their public images. This increased privacy stems from the fact that collaborative law involves negotiations that are conducted off the record and outside of the courtroom. ${ }^{171}$ Additionally, the jointly filed complaints in collaborative cases do not contain "lengthy statements of allegations, defenses, or denials." "Th2 "This [privacy] feature is precisely why collaborative law has expanded into civil cases, particularly those involving . . . employment disputes, and the breakup of business entities such as partnerships and joint ventures." ${ }^{, 173}$ For instance, in the case that Laura brought against her former employer, the company was agreeable to using collaborative law to settle the parties' dispute in part because, unlike litigation, the collaborative process would lessen the likelihood that the dispute would draw media attention or the scrutiny of employees in the company's other offices. ${ }^{174}$

Based on the fact that collaborative law may reduce expenses, increase employee productivity, and preserve privacy, "the 'track record' argument does not favor litigation unless one embraces the mindset that 'the devil [you] know is better than the one [you] don't know." "175

2. The Proper Screening of Collaborative Cases Protects Employers.Employers also argue that, if they use collaborative law as a method of dispute resolution, employees will view them as an "easy settle." ${ }^{176}$ This, they argue, will lead more employees to bring cases against them, thinking that they can reach a

165. Id.

166. Id. at 503 .

167. Id.

168. Id.

169. Id. at 502-03.

170. Id. at 502 .

171. Id.

172. Id.

173. Daicoff, supra note 22, at 131.

174. Abney, supra note 1, at 505 .

175. Zeytoonian, supra note 22.

176. Id. 
quick settlement without having to go to court. ${ }^{177}$

With respect to this concern, collaborative attorneys are employers' best allies because they are trained to perform an initial assessment of a case to determine whether it is a good candidate for collaborative law. ${ }^{178}$ Collaborative attorneys' initial assessment involves an evaluation of several factors: (1) whether the case involves a "legitimate, legal claim;" (2) whether there is a "viable defense" to the claim; (3) whether there are "interests involved other than money damages;" and (4) whether the parties are "capable of participating in a structured and transparent process of interest-based" negotiations. ${ }^{179}$ In other words, this initial assessment essentially ensures that the cases presented to employers for possible resolution through collaborative law are limited to those with merit, for which collaborative law makes more sense than litigation. ${ }^{180}$ Employers may encourage employees who have "a viable claim and the right set of variables" to use collaborative law. ${ }^{181}$ Consequently, under the right circumstances, using the "less expensive, less draining and less time consuming process" of collaborative law may result in a "win-win" scenario for both parties. ${ }^{182}$

3. Efficiency Concerns Favor Using Collaborative Law.-Employers argue that, in cases in which they have a solid defense and feel that they will win easily through litigation, it is more efficient not to take action until an employee actually files a claim with the court. ${ }^{183}$ However, in cases that are screened appropriately, "the efficiency argument will always favor using [collaborative law] over litigation." 184

There are only two remaining reasons why employers would choose litigation over collaborative law: (1) the employer wishes to create precedent using a particular case; or (2) the case involves a need for injunctive relief that only a court has the authority to grant. ${ }^{185}$ It is highly unlikely that an employer would want to create precedent using a particular case,${ }^{186}$ in part because it would draw public attention to the employer's dispute with its employee. Moreover, the parties could provide for injunctive relief in the settlement agreement that they reach through collaborative law, thereby avoiding the time and expense associated with filing a complaint, moving for injunctive relief, and attending a court hearing on the matter. ${ }^{187}$

177. $I d$.

178. $I d$.

179. $I d$.

180. $I d$.

181. Id.

182. Id.

183. Id.

184. Id.

185. Id.

186. Id.

187. Id. 


\section{B. Addressing Objections Raised by Attorneys}

Some attorneys view the disqualification requirement, or "withdrawal provision," as a barrier to using collaborative law in employment disputes. ${ }^{188}$ From a practical standpoint, many business lawyers object to the disqualification requirement, arguing that they would be unwilling to withdraw from cases in which they represent long-time clients in the event that the collaborative process breaks down. ${ }^{189}$ Additionally, there is some concern that the disqualification agreement will have a particularly negative impact "in the context of large law firms and contingent fee cases. ${ }^{190}$ However, most collaborative attorneys indicate that, "in practice, the withdrawal provision rarely creates a significant impediment to using the collaborative approach in commercial disputes."191 Specifically, if a potential collaborative case is properly vetted before the process begins, the attorneys will be able to gauge the parties' ability to participate in the collaborative process successfully. ${ }^{192}$ Moreover, if the collaborative attorneys involved in a case believe that the parties may be approaching an impasse, they may enlist the assistance of other professionals, including mediators, to work through a particularly complicated issue. ${ }^{193}$ Additionally, practitioners who believe that collaborative law may be used successfully in employment disputes will eventually be joined by more employers who recognize the value of its use as a method of dispute resolution and who demand that their attorneys use it. ${ }^{194}$

It is worth reiterating that, in a collaborative case, each party hires a collaboratively-trained attorney. ${ }^{195}$ As collaborative attorney Sherrie R. Abney stressed, "[n]ot every . . lawyer is suited to participate in the collaborative process. ... [This] is a fact that must be recognized and remembered." ${ }^{196}$ Many attorneys are accustomed to controlling the pace and the strategy of a case and they may not possess the patience to allow clients to dictate the dispute resolution process. ${ }^{197}$ Successful collaborative attorneys "listen more than they speak;" therefore, those attorneys who would rather control negotiations and suggest solutions may simply want to remain in litigation practice. ${ }^{198}$ Additionally, business and employment attorneys concerned with the alleged threat posed by the disqualification agreement may opt not to be trained in the collaborative approach to dispute resolution.

188. Fitzpatrick, supra note 28.

189. Id.

190. Larry Hance, Integrating Collaborative Law into a Traditional Family Law Practice, in Developing a Collaborative Family Law Practice 103 (Michaela Falls ed., 2011).

191. Fitzpatrick, supra note 28.

192. Zeytoonian, supra note 22.

193. Collaborative Law FAQs, supra note 97.

194. Hance, supra note 190.

195. Rubenstein, supra note 15.

196. Abney, supra note 1, at 498.

197. Id. at 499.

198. Id. 


\section{A Collaborative Law Success Story: Laura's Sexual Harassment and Retaliation Case}

Laura's sexual harassment and retaliation case against her former employer provides a perfect example of how a collaborative employment law case proceeds in practice. Once Laura decided to pursue resolution of her employment dispute through collaborative law, her attorney reached out to her former employer. ${ }^{199}$ Fortunately, the company was receptive to the idea of using collaborative law to resolve the dispute. ${ }^{200}$ Before any substantive negotiations began, the collaborative attorneys informed the parties that their statements should focus on how the issues in the "dispute had affected each of them and what options were available for the future," rather than on why the other party was at fault. ${ }^{201}$

At the parties' first collaborative meeting, Laura expressed her feelings and concerns, explaining that the harassment incident had made her feel cheap, to the point that she questioned whether other people viewed her in the same way that the shop manager did. ${ }^{202}$ Laura also stated that, when she began to look for a new position, she experienced difficulty in explaining why she left her last job. ${ }^{203}$ She worried that, if she mentioned the sexual harassment issue, potential employers would consider her to be a "source of trouble." ${ }^{204}$ On the other hand, Laura did not want to state that the company had fired her for not meeting company standards because she did not believe that to be true and because she feared that employers would view her as being unqualified. ${ }^{205}$

Laura further explained that the mental and emotional stress created by her situation caused her health to decline to the extent that she sought medical treatment, which included a short hospital stay. ${ }^{206}$ Her extreme stress, she related, was largely due to her feeling that her former employer punished her unfairly. ${ }^{207}$ She did not know whether her former employer disciplined the shop manager because she was too humiliated to ask her former co-workers. ${ }^{208}$ Laura concluded by saying that she felt as though "everyone at the company must have a poor opinion of her because no one had even apologized regarding the shop manager's behavior." 209

After listening attentively to Laura's statements, Matt, who served as the company's representative during the collaborative process, took a moment to collect his thoughts. ${ }^{210} \mathrm{He}$ first acknowledged that Laura's behavior could not

199. Id. at 505 .

200. Id.

201. Id. at 506.

202. Id.

203. Id.

204. Id.

205. Id.

206. Id.

207. Id.

208. Id.

209. Id.

210. Id. 
have invited the shop manager's inappropriate conduct under any circumstances. ${ }^{211}$ Matt also apologized for what happened to Laura and assured her that the shop manager had been told, in no uncertain terms, that any similar incident would result in his immediate termination. ${ }^{212}$ As a result of Laura's reporting the shop manager's behavior, Matt explained, the company hired a human-relations consultant to conduct a mandatory program on all forms of harassment and discrimination. ${ }^{213}$

Matt also addressed Laura's impression that her former employer terminated her for reporting the incident. ${ }^{214} \mathrm{He}$ clarified that the company was in the midst of restructuring at the time that Laura reported the shop manager's behavior. ${ }^{215}$ This restructuring led to the elimination of several positions; employees were laid off in accordance with their education, experience, and seniority. ${ }^{216}$ Unfortunately, Laura was laid off because: (1) she did not have a college education; (2) her position was being eliminated; and (3) there were no lateral openings within the company. ${ }^{217}$ Emphasizing that Laura's reporting of the incident and her termination were entirely unrelated events, Matt nevertheless acknowledged that he could understand why Laura felt that the occurrences were connected. ${ }^{218}$

Ultimately, the parties agreed that the company would pay Laura's medical bills, her collaborative attorney's fees, and her salary until she found a new position. ${ }^{219}$ Most importantly, Laura received a form of relief that likely would not have been delivered through litigation: a genuine apology from her former employer. ${ }^{220}$

\section{CONCLUSION}

Laura's case serves as a perfect example of the benefits that employees and employers may enjoy when using collaborative law to resolve their disputes. From the very beginning of the case, the parties' collaborative attorneys focused on facilitating communication and ensuring that the parties, for the purposes of negotiation, were placed on equal footing. ${ }^{221}$ This, in turn, provided Laura with a safe environment in which she could fully express how the harassment incident affected her emotionally, physically, and professionally. ${ }^{222}$ Likewise, Matt was able to answer the allegations that Laura made against his company calmly, while

\footnotetext{
211. Id.

212. Id.

213. Id. at 506-07.

214. Id. at 507.

215. Id.

216. Id.

217. Id.

218. Id.

219. Id.

220. $I d$.

221. Id. at 506.

222. Id.
} 
also offering an apology for what happened to Laura. ${ }^{223}$

If the parties had chosen to litigate their dispute, each would have faced significant hardships. For instance, each party would have lost a substantial amount of privacy. ${ }^{224}$ Laura would have been forced to relive the humiliation of the incident and of her termination in pleadings, depositions, and likely in open court. ${ }^{225}$ Similarly, her former employer would have had to contend with the public's and employees' reactions to Laura's accusations. ${ }^{226}$ Additionally, although a jury or court may have awarded Laura monetary damages, which could have covered her medical bills, she likely would not have received a heartfelt apology from her former employer. ${ }^{227}$

Other parties involved in employment disputes easily may enjoy the benefits of engaging in the collaborative process, such as: (1) saving time and money; (2) enjoying greater privacy; (3) having more input in the decision-making process; (4) increasing both parties' compliance with the settlement agreement(s) that they personally crafted; and (5) effectively mitigating any conflict between the parties. ${ }^{228}$ Employers may confidently choose to settle their disputes using collaborative law, knowing: (1) that collaborative law is rapidly gaining favor both domestically and internationally; ${ }^{229}(2)$ that the collaborative case screening process prevents employees from using collaborative law to create frivolous disputes ${ }^{230}$ and (3) that efficiency concerns favor the use of collaborative law. ${ }^{231}$ Similarly, clients like Laura may take comfort in knowing that they will have an opportunity to be heard fully through the collaborative law process without facing the scrutiny of judges or juries. ${ }^{232}$ It is high time that more parties to employment disputes take advantage of collaborative law as a form of dispute resolution.

223. Id. at 506-07.

224. Id. at 505 .

225. $I d$.

226. Id.

227. Id. at 507.

228. Daicoff, supra note 22, at 130-33.

229. Id. at 118; IACP-Connecting the Global Collaborative Community, supra note 41.

230. Zeytoonian, supra note 22.

231. Id.

232. Rubenstein, supra note 15. 